\title{
Hubungan antara Perilaku Seksual dengan Tingkat Pengetahuan Agama Islam pada Siswa Sekolah Menengah Kejuruan (SMK)
}

\author{
$\underline{\text { Abdul Basit }}$ \\ Akademi Kebidanan Alifa Pringsewu Lampung \\ Jl. Jend. Ahmad Yani, Gg. Gunung Sari Sidoharjo No. 5 Pringsewu \\ Email:abdul.basit3428@yahoo.com
}

\begin{abstract}
ABSTRAK
Gejala perilaku seksual di kalangan pelajar sudah mewabah hampir di seluruh pelosok tanah air. Data menunjukkan dari 62 juta remaja di Indonesia, 21 juta atau 32\% diantaranya sudah pernah melakukan hubungan seksual sebelum menikah. Di Indonesia, agama masih diyakini sebagai salah satu sumber untuk memperoleh nilai moral atau norma perilaku. Tidak adanya moral dan agama seringkali dituduh sebagai penyebab meningkatnya kenakalan remaja. Penelitian ini bertujuan untuk mengetahui hubungan antara perilaku seksual remaja dengan tingkat pengetahuan agama Islam. Penelitian ini merupakan analitik korelasional dengan pendekatan Cross Sectional. Variable bebas dalam penelitian ini adalah tingkat pengetahuan agama Islam dan variabel terikat yaitu Perilaku Seksual Siswa SMK. Populasi penelitian ini yaitu siswa kelas X dan XI SMK yang berjumlah 576 siswa. Pengambilan sampel menggunakan pendekatan probability sampling yaitu sejumlah 132 siswa. Analisis data penelitian menggunakan perhitungan korelasi dengan teknik Chi-square. Hasil analisis statistik menunjukkan nilai Pearson Chi-square sebesar 1,606 a dengan Asymp. Sig. (2-sided) sebesar 0,448 atau lebih besar dari 0,05 artinya nilai korelasinya sangat lemah, sehingga hasilnya tidak terdapat hubungan antara kedua variabel yang diteliti yaitu tingkat pengetahuan agama Islam dengan perilaku seksual pada siswa SMK KH. Gholib Pringsewu.
\end{abstract}

Kata Kunci: Perilaku Seksual, Remaja, Pengetahuan, Agama

CORELATIONS BETWEEN SEXUAL BEHAVIOR WITH LEVEL OF ISLAMIC RELIGIOUS KNOWLEDGE IN STUDENT OF VOCATIONAL HIGH SCHOOL (SMK)

\begin{abstract}
Symptoms of sexual behavior among learners has spread across the country. Data show that of 62 million adolescents in Indonesia, 21 million or 32\% of whom have had sexual intercourse before marriage. In Indonesia, religion is still believed as one source to obtain moral values or behavioral norms. The absence of morals and religion is often accused of causing increased juvenile delinquency. This study aims to determine the relationship between adolescent sexual behavior with the level of knowledge of Islam. This research is correlational analytic with Cross Sectional approach. Independent variable in this study is the level of knowledge of Islam and the dependent variable of Sexual Behavior SMK Students. The population of this study are students of class X and XI SMK, amounting to 576 students. Sampling using probability sampling approach that is a number of 132 students. Analysis of research data using correlation calculation with Chi-square technique. The result of statistical analysis showed Pearson Chi-square value of 1.606a with Asymp. Sig. (2sided) of 0.448 or greater than 0.05 means the correlation value is very weak, so the result there is no relationship between the two variables studied is the level of knowledge of Islam with sexual behavior Students SMK KH. Gholib Pringsewu.
\end{abstract}

Key Words: Sexual Behavior, Adolescent, Knowledge, Religion

How to Cite: Basit, Abdul. (2017). Hubungan antara Perilaku Seksual dengan Tingkat Pengetahuan Agama Islam pada Siswa Sekolah Menengah Kejuruan (SMK). Jurnal Aisyah: Jurnal Ilmu Kesehatan. 2 (2), $175-180$. 


\section{PENDAHULUAN}

Gejala perilaku seksual di kalangan pelajar (remaja) sudah mewabah hampir di seluruh pelosok tanah air. Hasil Survey BKKBN bekerjasama dengan LD-FEUI pada tahun 1999 terhadap 8084 remaja laki-laki dan remaja putri usia 15 - 24 tahun di 20 kabupaten pada empat propinsi (Jawa Barat, Jawa Tengah, Jawa Timur, dan Lampung) terpapar data sebanyak $46,2 \%$ remaja beranggapan bahwa perempuan tidak akan hamil hanya dengan sekali melakukan hubungan seks. (Deidy Tjahayadi, 2009). Lebih lanjut dalam harian Kompas (2005) yang dikutip oleh Tjahayadi (2009), sebuah survei yang juga pernah dilakukan di 4 kota (Jakarta, Bandung, Surabaya dan Lampung) pada 450 responden yang berusia antara 15 â 24 tahun diketahui sebanyak $37 \quad \%$ responden laki-laki mengaku merencanakan untuk berhubungan intim saat pacaran dan sebanyak $39 \%$ responden perempuan mengaku selalu dibujuk untuk berhubungan intim saat pacaran. Sedangkan tempat favorit dan aman menurut responden untuk melakukan aktivitas seksual adalah di rumah, tempat kost, dan hotel.

Berdasarkan situs media online republika.co.id diakhir tahun 2012, terdata total remaja Indonesia sekitar 62 juta, sekitar 21 juta remaja atau 32\% diantaranya sudah pernah melakukan hubungan seksual sebelum menikah. Dalam berita itu juga mengungkapkan bahwa hasil penelitian di empat kota, yakni Jakarta Pusat, Medan, Bandung, dan Surabaya oleh Kementerian Kesehatan (Kemenkes) tentang perilaku seks bebas remaja didapat sebanyak 35,9\% remaja mempunyai teman yang sudah pernah melakukan hubungan seksual sebelum menikah. Media online tempo.co memasang berita tentang perilaku seks bebas remaja pada Mei tahun ini. Hardianto, Deputi Advokasi, Pergerakan dan Informasi BKKBN Pusat mengungkapkan bahwa 64 juta remaja Indonesia masih rentan melakukan seks bebas. Salah satu indikasinya adalah tingkat kelahiran pada usia remaja terjadi 48/1000 kelahiran.

Dari data-data tersebut menunjukan dari tahun ke tahun masih tingginya angka perilaku seksual yang negatif dikalangan remaja, bahkan cenderung meningkat jumlahnya, hal tersebut bisa diakibatkan dari pergaulan bebas remaja dan betapa bebasnya mengakses berbagai macam konten porno di internet.

Masa remaja adalah masa transisi yang ditandai adanya perubahan dan pertumbuhan baik fisik, psikis serta sosial sebelum akhirnya menjadi kategori dewasa pastinya mengalamim perkembangan. Batasan usia remaja menurut WHO (World Health Organisation) adalah usia 12 tahun sampai 24 tahun. Menurut Depkes RI antara 10-19 tahun dan belum kawin. Menurut BKKBN (Badan Koordinasi Keluarga Berencana Nasional) adalah antara 10-19 tahun.

Perkembangan serta kematangan seksual yang tidak diiringi dengan pengetahuan agama khususnya tentang seksual tentunya akan menjadi penyebab rusaknya moral remaja dalam kancah seksualitas. Yang akhirnya terlibat dalam seks bebas, seks pranikah, dan penyimpangan orientasi seksual. Perlu adanya penanaman pengetahuan serta pendidikan agama yang mampu menjadi pengontrol perilaku seksual remaja. Di Indonesia, agama masih diyakini sebagai salah satu sumber untuk memperoleh nilai moral atau norma perilaku. Agama/ religi merupakan bagian yang cukup penting dalam jiwa remaja. Bahkan tidak adanya moral dan agama seringkali dituduh sebagai penyebab meningkatnya kenakalan remaja (Panuju, 1999).

Dari uraian diatas, maka peneliti tertarik untuk melaksanakan penelitian mengenai hubungan tingkat pengetahuan agama Islam dan perilaku seksual remaja Siswa SMK. 


\section{METODE PENELITIAN}

Jenis penelitian ini merupakan penelitian analitik korelasional dengan pendekatan Cross Sectional, karena dalam penelitian ini terdapat dua Variabel yakni variabel bebas yaitu Tingkat Pengetahuan Agama Islam Dan variabel terikat yaitu Perilaku Seksual Remaja Siswa SMK KH. Gholib Pringsewu. Sedangkan populasinya terdiri dari Populasi Target dan Populasi Aktual, populasi targetnya adalah siswa SMK KH. Gholib Pringsewu dan populasi aktualnya siswa-siswi SMK KH. Gholib Pringsewu dari kelas X sebanyak 311 siswa dan kelas XI sebanyak 265 siswa.

Populasi dalam penelitian ini yaitu siswa kelas $\mathrm{X}$ dan XI berjumlah 576 siswa. Sedangkan Pengambilan sampel dalam penelitian ini menggunakan pendekatan probability sampling dan teknik yang digunakan dalam penelitian ini adalah simple random sampling yang merupakan teknik pengambilan sampel untuk tujuan tertentu. Dalam penelitian ini populasi lebih dari seratus yaitu 576 siswa, maka peneliti mengambil memilih $23 \%$ dari jumlah populasi tersebut yakni 132 siswa.

Analisis data dengan Univariat yaitu karakteristik responden, variabel tingkat pengetahuan agama Islam dan variabel perilaku seksual dan Analisis Bivariatnya menggunakan uji Chi-Square dengan bantuan program SPSS. Analisa ini digunakan untuk melihat hubungan atau pengaruh antara variabel dependen dan variabel independen.

\section{HASIL DAN PEMBAHASAN}

Berdasarkan tabel 1. Karakteristik responden berdasarkan informasi pengetahuan Agama Islam adalah siswasiswi SMK KH. Gholib Pringsewu paling banyak mendapatkan informasi dari guru Agama Islam disekolah yaitu sebanyak 51 siswa-siswi (38, 6\%). Sedangkan sumber informasi yang paling sedikit digunakan oleh siswa-siswi adalah dari media cetak sebanyak 1 siswa/siswi $(0,8 \%)$.

Tabel 1. Karakteristik Responden Berdasarkan Sumber Pengetahuan Agama Islam

\begin{tabular}{|c|c|c|}
\hline Sumber Informasi Pengetahuan Agama Islam & Frekuensi & Persentase \\
\hline Guru/ Ustadz di Daerah masing-masing & 34 & $25,8 \%$ \\
\hline Guru Agama Islam di sekolah & 51 & $38,6 \%$ \\
\hline Media Cetak : Buku-buku/ Majalah pelajaran Islam & 1 & $0,8 \%$ \\
\hline Internet dan Televisi & 2 & $1,5 \%$ \\
\hline Lebih dari 1 sumber & 44 & $33,3 \%$ \\
\hline Jumlah & 132 & $100 \%$ \\
\hline
\end{tabular}

Tabel 2. Tingkat Pengetahuan Agama Islam Responden Penelitian

\begin{tabular}{lcc}
\hline $\begin{array}{c}\text { Tingkat Pengetahuan } \\
\text { Agama Islam }\end{array}$ & Frekuensi & Persentase \\
\hline Rendah & 2 & $1,5 \%$ \\
\hline Sedang & 18 & $13,6 \%$ \\
\hline Baik & 112 & $84,8 \%$ \\
\hline \multicolumn{1}{c}{ Jumlah } & 132 & $100 \%$ \\
\hline
\end{tabular}

Tabel 2. Menunjukkan bahwa dari 132 siswa SMK KH. Gholib Pringsewu terdapat siswa yang berpengetahuan rendah yaitu 2 orang siswa $(1,5 \%)$, sebanyak 18 siswa
(13, $6 \%)$ berpengetahuan sedang dan 112 siswa $(84,8 \%)$ berpengetahuan baik.

Tabel 3. Distribusi Frekuensi Perilaku Seksual Siswa SMK

\begin{tabular}{|c|c|c|}
\hline $\begin{array}{c}\text { Perilaku Seksual } \\
\text { Remaja }\end{array}$ & Frekuensi & Persentase \\
\hline Positif & 92 & $69,7 \%$ \\
\hline Negatif & 40 & $30,3 \%$ \\
\hline Jumlah & 132 & $100 \%$ \\
\hline
\end{tabular}




\section{Jurnal Aisyah: Jurnal Ilmu Kesehatan 2 (2) 2017, - 178}

Abdul Basit

Berdasarkan tabel 3. dapat diketahui bahwa dari 132 responden SMK KH. Gholib Pringsewu diperoleh data siswa yang mempunyai perilaku Positif sebanyak 92 orang $(69,7 \%)$ dan yang mempunyai perilaku negatif sebanyak 40 orang $(30,3 \%)$.

Perhitungan korelasi dengan Chi-square dengan bantuan program SPSS 22 for Windows menghasilkan nilai Pearson ChiSquare sebesar 1,606 dengan Asymp. Sig. (2-sided) sebesar 0, 448 atau lebih besar dari 0, 05. Bila nilai Asymp.Sig lebih besar dari 0, 05 maka dapat dinyatakan tidak terdapat hubungan antara kedua variabel yang diteliti yaitu tingkat pengetahuan agama Islam dengan perilaku seksual remaja. Berdasarkan perhitungan tersebut diperoleh data bahwa tidak ada hubungan antara tingkat pengetahuan agama Islam dengan perilaku seksual remaja.

Pada perhitungan tingkat pengetahuan agama Islam pada siswa-siswi SMK KH. Gholib Pringsewu didapatkan hasil yang cukup membanggakan karena hanya 1, 5\% responden yang memiliki tingkat pengetahuan yang rendah. Tingkat pengetahuan responden tentang agama Islam sebagian besar mempunyai tingkat pengetahuan yang baik/ tinggi $(84,8 \%$ dan sebanyak 13, 6\% memiliki tingkat pengetahuan yang sedang. Dikatakan memiliki tingkat pengetahuan baik karena mampu menjawab pertanyaan kuesioner dengan benar sebanyak 76-100 \% pertanyaan dan berpengetahuan sedang karena mampu menjawab 56-75 \% pertanyaan. Menurut Notoatmodjo (2007), ada beberapa faktor yang mempengaruhi tingkat pengetahuan seseorang, antara lain adalah pendidikan dan informasi. Siswasiswi SMK KH. Gholib Pringsewu telah mendapatkan informasi mengenai agama Islam dari guru agama Islam di sekolah dan ustadz/ guru agama di daerah masingmasing.Sedangkan pada perilaku seksual remaja terlihat data perilaku seksual remaja pada siswa-siswi SMK KH. Gholib sebagian besar mempunyai perilaku positif (69, 7\%), namun ada juga remaja yang berprilaku negatif $(30,3 \%)$. Remaja yang berperilaku positif adalah remaja yang dalam hasil mean total skor prilaku dari penghitungan dengan bantuan program SPSS 22 for Windows lebih besar dari 28 . 88 dari pertanyaan yang diajukan yaitu membaca buku porno, menonton video/ film porno, mengkhayal atau memikirkan fantasi seks, melakukan onani/ masturbasi, berpelukan dengan lawan jenis, berciuman pipi, berciuman bibir, hingga leher dan dada dan meraba-raba bagian tubuh kekasih. Sedangkan siswa/ siswi yang berprilaku negatif ialah siswa/ siswi yang dalam hasil mean total skor prilaku dari penghitungan dengan bantuan program SPSS 22 for Windows lebih kecil dari 28.88 dari pertanyaan yang diajukan, dan pilihannya jawabannya ialah sesuai kondisi perilaku masing-masing yaitu diberi pilihan jawaban Tidak Pernah (TP), Jarang (J), Kadangkadang (KK), Sering (S).

Berdasarkan hasil pengolahan data menggunakan perhitungan korelasi dengan Chi-square dengan bantuan program SPSS 22 for Windows menghasilkan nilai Pearson Chi-Square sebesar 1,606 a dengan Asymp. Sig. (2-sided) sebesar 0, 448 atau lebih besar dari 0, 05. Bila nilai Asymp.Sig lebih besar dari 0,05 berarti nilai korelasinya sangat lemah, maka dapat dinyatakan tidak terdapat hubungan antara kedua variabel yang diteliti yaitu tingkat pengetahuan agama Islam dengan perilaku seksual remaja. Nilai korelasi yang sangat lemah menunjukkan bahwa terdapat faktorfaktor lain yang mempengaruhi perilaku seksual selain pengetahuan.

Peran-peran agama yang semakin terpinggirkan dan hanya difahami secara teori saja, menyebabkan seseorang secara lebih permisif terhadap perilaku seksual pranikah. Dengan demikian perilaku seksual pranikah yang terjadi didasari oleh tingkat pemaknaan keagamaan yang rendah. Faktor agama yang dijelaskan 


\section{Jurnal Aisyah: Jurnal Ilmu Kesehatan 2 (2) 2017, - 179}

Abdul Basit

dalam Kaisar Family Foundation oleh Santrock (2003) yaitu berupa keadaan iman yang rapuh. Individu yang rapuh imannya akan cendrung mudah untuk melakukan penyimpangan-penyimpangan terhadap ajaran agamanya. Jadi faktor lain yang mempengaruhi perilaku seksual remaja ialah dapat dilihat dari seberapa besar sikap beragamanya terhadap ajaran agamanya khususnya dalam hal perilaku seksual yang menyimpang. Hal ini sesuai dengan penelitian yang dilakukan oleh Rohdi (2003) menunjukan bahwa semakin tinggi sikap beragama seseorang maka akan semakin rendah kecendrungan perilaku seks pranikah, begitu juga dengan sebaliknya semakin rendah sikap beragama seseorang maka akan semakin tinggi kecendrungan perilaku seks pranikah seseorang.

Faktor lain yang menyebabkan masih tingginya perilaku seksual negatif remaja SMK. KH. Gholib Pringsewu (30,3\%) meskipun tingkat pengetahuan agama Islam yang tinggi $(84,8 \%)$ ialah karena ada beberapa fakta terbaru di Indonesia, dari sekitar 1,8 juta penduduk Indonesia telah mengenal internet dan $50 \%$ diantaranya tidak mampu menahan diri untuk tidak membuka situs porno (Najma, 2009). Padahal paparan informasi seksual melalui internet tidak begitu banyak memberikan kontribusi positif bagi remaja. Informasi yang sifatnya mendidik masih kurang memadai. Keadaan ini akan menimbulkan kecenderungan pelanggaran perilaku seksual yang semakin meningkat (Laksmiwati, 2008).

Namun demikian walaupun tidak terdapat hubungan yang signifikan antara tingkat pengetahuan agama Islam dan perilaku seksual remaja SMK. KH. Gholib Pringsewu yang bisa karena faktor-faktor lain, angka tingkat pengetahuan agama Islamnya yang baik/ tinggi sangat membanggakan yaitu $84,8 \%$ dan juga perilaku postifnya juga besar yaitu $69,7 \%$, berarti tingkat pengetahuan agama Islam membawa pengaruh terhadap perilaku seksual remaja SMK. KH. Gholib Pringsewu meskipun tidak terdapat hubungan.

\section{KESIMPULAN}

Berdasarkan hasil penelitian dan pembahasan dapat disimpulkan bahwa tingkat pengetahuan agama Islam SMK KH. Gholib Pringsewu diperoleh data yaitu siswa yang berpengetahuan rendah yaitu 2 orang siswa (1, 5\%), sebanyak 18 siswa $(13,6 \%)$ berpengetahuan sedang dan yang paling tinggi yaitu 112 siswa $(84,8 \%)$ berpengetahuan baik, sedangkan perilaku seksual remaja SMK KH. Gholib Pringsewu diperoleh data yaitu siswa/ siswi yang mempunyai perilaku Positif sebanyak 92 orang $(69,7 \%)$ dan yang mempunyai perilaku negatif sebanyak 40 orang $(30,3 \%)$. Sehingga tidak terdapat hubungan antara kedua variabel yang diteliti yaitu tingkat pengetahuan agama Islam dengan perilaku seksual remaja. Nilai korelasi yang sangat lemah menunjukkan bahwa terdapat faktor-faktor lain yang mempengaruhi perilaku seksual selain pengetahuan. Namun demikian walaupun tidak terdapat hubungan yang signifikan antara tingkat pengetahuan agama Islam dan perilaku seksual remaja SMK. KH. Gholib Pringsewu yang bisa karena faktor-faktor lain, angka tingkat pengetahuan agama Islamnya yang baik/ tinggi sangat membanggakan yaitu $84,8 \%$ dan juga perilaku positifnya juga besar yaitu $69,7 \%$, berarti tingkat pengetahuan agama Islam membawa pengaruh terhadap perilaku seksual remaja SMK. KH. Gholib Pringsewu meskipun tidak terdapat hubungan. 


\section{DAFTAR PUSTAKA}

Arikunto, S. (2006). Prosedur Penelitian: Suatu Pendekatan Praktek. Jakarta: Rineka Cipta.

Ghozali, I. (2002). Aplikasi Analisis Multivariat dengan Program SPSS. Semarang: Badan Penerbit Universitas Diponegoro.

Handayani, S. (2016). Pengetahuan Agama Berhubungan Dengan Perilaku Seksual Pada Remaja Di SMAN 1 Soppeng Riaja Kab. Baru, Jurnal Kesehatan Masyarakat, Vol.1, No.4

Hanifah, F. (2013). Hubungan Kontrol Sosial Orang Tua Dengan Perilaku Seks Pranikah Remaja Kelurahan Batang Arau Kecamatan Padang Selatan, SPEKTRUM PLS, Vol. I, No. 2

Hidayat, A. A. (2007). Metode Penelitian Kebidanan \& Teknik Analisis Data. Jakarta: Salemba Medika

Hurlock, Elizabeth. (2004). Psikologi Perkembangan Suatu Pendekatan Sepanjang Rentang Kehidupan. Jakarta: Erlangga.

Laksmiwati, I. A. A. (2008) "Transformasi Sosial dan Perilaku Reproduksi Remaja”, BKKBN, diakses pada tanggal 10 Juli 2017

http://ceria.bkkbn.go.id/penelitian/d etail/495

Mansyah, H. (2013). 20, 9 Persen $A B G$ Hamil di Luar Nikah. Lampung Post: 10

Ali, Mohammad. Daud. (2006). Pendidikan Agama Islam. Jakarta: Raja Grafindo Persada
Notoatmodjo, S. (2003). Ilmu Kesehatan Masyarakat (Prinsip-Prinsip Dasar). Jakarta: Rineka Cipta.

-------. (2007). Promosi Kesehatan. Jakarta: Rineka Cipta.

--------. (2010). Metodologi Penelitian Kesehatan. Jakarta: Rineka Cipta.

Nursalam. (2003). Konsep dan Penerapan Metodologi Penelitian Ilmu Keperawatan. Jakarta: Salemba Medika.

Panuju, P. (2007). Psikologi Remaja. Jakarta: Raja Grafindo Persada.

Parliza, Herdrawan. (2013). 64 Juta Remaja Galau Rentan Seks Bebas, tempo.com. diakses tanggal 28 Juli 2017 ,

https://nasional.tempo.co/read/4795 16/64-juta-remaja-galau-rentanseks-bebas.

Abdullah Sammy. (2012). Wah 21 Juta Remaja Indonesia Sudah Berhubungan Seks, Republika Online, diakses tanggal 28 Juli 2017 ,

http://www.republika.co.id/berita/na sional/umum/12/12/21/mfd481wah-21-juta-remaja-indonesiasudah-berhubungan-seks.

Sarwono, S. W. (2000). Psikologi Remaja. Jakarta: Raja Grafindo Persada.

Sugiyono. (2014). Metode Penelitian Kuantitatif Kualitatif dan $R \& D$. Bandung: Alfabeta.

Tjahayadi, D. (2009). Permasalahan Kesehatan Reproduksi Remaja. BKKBN, Diakses 22 Mei 2017. http://lampung.bkkbn.go.id/ 